\title{
HOW MULTIMODALITY SHAPES CREATIVE CHOICE IN DANCE
}

\author{
CÓMO LA MULTIMODALIDAD CONFIGURA LA DECISIÓN CREATIVA \\ EN DANZA
}

\author{
DAfNe MunTANYola dafne.muntanyola@uab.cat \\ Universidad Autónoma de Barcelona. Spain.
}

\begin{abstract}
Creative choice is an individual act. As in other fields such as filmmaking, dance creation is based on a cognitive dualism that considers the choreographer as the creative decision-maker, while the dancer is objectified. The dancer's body is an instrument for exploration of the choreographer's imagery. We claim that the products of creativity are minute but crucial modifications of transitory stages of a dance rehearsal. On the one hand, attention is given to a dance company as a distributed cognitive system. The choreographer communicates in diverse modalities, which carry specific information, physical as well as symbolic. Through the analysis of an audiovisual and cognitive ethnography with ELAN software we find differences in decision-making patterns across multimodal instructions. On the other hand, we apply Social Network Analysis and UCINET software as a methodological innovation in order to formalize data from observed rehearsal settings. In all, the choice of modalities in the chorographical instruction shapes movement production, which is based on dyads, triads and other forms of creative interaction.
\end{abstract}

\section{KEYWORDS}

Creativity; Dance; ELAN; Interaction; Multimodality; Social Networks Analysis.

\section{RESUMEN}

La toma de decisión creativa es un acto individual. El cuerpo de la bailarina es un instrumento para la exploración de las imágenes del coreógrafo. Al igual que en otros campos artísticos, como la industria cinematográfica, la creación en danza se basa en un dualismo cognitivo. Se considera al coreógrafo como el tomador de decisiones creativo, mientras que el bailarín se objetiva. En este artículo, afirmamos que los productos de la creatividad son modificaciones pequeñas pero cruciales de etapas transitorias de un ensayo de baile. Por un lado, se analiza una compañía de danza como un sistema cognitivo distribuido. A través del análisis de una etnografía audiovisual y cognitiva con ELAN encontramos diferencias en los patrones de toma de decisions. El coreógrafo se comunica con diversas modalidades, que llevan información específica, tanto de tipo físico como simbólico. Por otra parte, realizamos un Análisis de Redes Sociales con UCINET como una innovación metodológica. Así formalizamos los datos recogidos en los ensayos observados. En definitiva, la elección de las modalidades en la instrucción coreográfica da forma a la producción de movimiento, que se basa en díadas, tríadas y otras formas de interacción creativa.

\section{Palabras clave}

Análisis de Redes Sociales; Creatividad; Danza; ELAN; Interacción; Multimodalidad. 


\section{INTRODUCTION}

In the art field, professionals define creative choice as a strictly individual act. However, creativity is also a product of interactive exchanges that are expressed not only by the individual but also by the group (Feyerabend 1987). Our main objective is to subvert the conventions that work at the level of micro decisions in dance (Becker 1999). Instead of defining the conventions as guidelines for coordination between the choreographer and the dancers, we will focus on these cooperation bonds and determine their functional role in the production of new dance moves. We analyze interaction, the smallest unit of analysis in sociology, within a cognitive ethnography of a dance company.

Our general hypothesis is that the choreographer's creativity goes beyond individual intentions to become an emerging product of the dance company. Extended rehearsal observation allowed us to define the chorographical act as the product of the choreographer's selective attention selection to the dancing material. Following the contributions of distributed knowledge (Hollan, Hutchins \& Kirsh 2000), multimodal action (Alac 2003) and cognitive sociology (Knorr-Cetina 1999), we provide a detailed video analysis with ELAN software, for analyzing sequence of filmed interaction and UCINET, a key software for Social Network Analysis.

A sample of solos, duets and trios constitutes our empirical material to test the distributed and multimodal nature of dance instruction. Longitudinal research of a prestigious company based in London sets up the ground for claiming that the dance rehearsals are built on social relations of production. This paper acknowledges the ties of mutual repression that are at the base of any artistic decision-making.

\section{Methods}

Cognitive ethnography is an innovative approach to creativity studies, which typically focus either on micro individual decisions, reasons and conventions (Faulkner \& Becker 2009; Buscatto 2008; Sorignet 2004; Becker 1999), or on the objective distribution of capital and resources in the professional hierarchy (Rannou \& Roarik 2006; Menger 2002; Bourdieu 1998). Without denying these theoretical positions we adopt a new angle, fully empirical and relational, which will allow us to formalize the relations of production in dance.

This paper is the result of a cognitive ethnography in San Diego and London of two dance rehearsals, DYAD1909, from January to November 2009, and FAR, between September and November 2010, by the London-based company WayneMcGregor-Random Dance. Professor David Kirsh and his team, from the Cognitive Science department at the University of California, San Diego (UCSD) placed seven high-resolution cameras $(\mathrm{HD})$ on the ceiling and walls of the theater, in order to film the entire rehearsals from 11 am to $5 \mathrm{pm}$, six days a week. UCSD students and expert ethnographers took field notes, and daily interviewed the dancers and the choreographer (Figure 1 and 2). 
Figure 1 and 2.

Field notes and interviews, UCSD, 2010

\begin{tabular}{|c|c|c|c|c|c|}
\hline \multicolumn{2}{|c|}{$\begin{array}{l}\text { DATE OF CODING } \\
\text { CODER NAME } \\
\text { VIDEO NAME }\end{array}$} & \multicolumn{4}{|c|}{$\begin{array}{l}\text { Day \# } 3 \\
\text { your name: Dafne Muntanyola } \\
\text { Day3-CLIP.mp4 }\end{array}$} \\
\hline 崖疍 & $\begin{array}{l}\text { DESCRIPTION OF ACTIVITY } \\
\text { (with dancers codes) }\end{array}$ & $\begin{array}{c}\text { CODES } \\
\text { (from the list) }\end{array}$ & COMMENTS & CODES & \\
\hline \multicolumn{2}{|c|}{ Wednesday July 24th } & & & KEY & Definition \\
\hline$\underset{\mathfrak{N}}{\stackrel{\sim}{*}}$ & $\begin{array}{l}\text { W tasks them (Highjacking). He } \\
\text { instructs in a group and asks } \\
\text { questions to the dancers. }\end{array}$ & Task & $\begin{array}{l}\text { (Try to get all the possible } \\
\text { instructions if you can hear } \\
\text { them). }\end{array}$ & 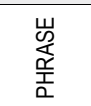 & \\
\hline \multirow[t]{2}{*}{ ્ֻల్ } & $\begin{array}{l}\text { W is watching the dancers after } \\
\text { tasking. The dancers are prac- } \\
\text { ticing in duets, K-R, S-T, MJ-C, } \\
\text { D-H, J-?, A-MJ }\end{array}$ & $\begin{array}{l}\text { Task, } \\
\text { Practice, } \\
\text { ob, DC }\end{array}$ & $\begin{array}{l}\text { There is a dancer I don't } \\
\text { know (?). }\end{array}$ & 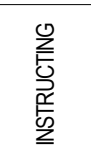 & $\begin{array}{l}\text { A form of communication describing } \\
\text { how a mvmt should be done. }\end{array}$ \\
\hline & $\begin{array}{l}\text { W is riffing off } \mathrm{J} \text {, he is slowly } \\
\text { moving his arms }\end{array}$ & $\mathrm{Rf}, \mathrm{Ob}$ & $\begin{array}{l}\text { In the task he said he } \\
\text { wants the dancers to feel } \\
\text { the movement, fall into } \\
\text { it, the quality of it, which } \\
\text { is what he seems to be } \\
\text { looking for in his riffing }\end{array}$ & $\lg$ & $\begin{array}{l}\text { Instructing to group: Dancer(s), } 0 \text { or } \\
\text { W gives instructions to group }\end{array}$ \\
\hline 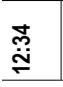 & $\begin{array}{l}\text { The dancers are using multiple } \\
\text { modalities to create new moves. }\end{array}$ & $\begin{array}{l}\text { Mod Talk, } \\
\text { FO, DC }\end{array}$ & $\begin{array}{l}\text { The dancers move and } \\
\text { stop regularly to talk }\end{array}$ & li & $\begin{array}{l}\text { Instructions to individuals: } \\
\text { Dancer(s), O, W gives instructions } \\
\text { to specific dancer }\end{array}$ \\
\hline \multicolumn{2}{|c|}{ Thursday July 25th } & & & 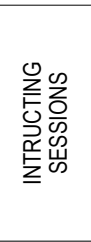 & $\begin{array}{l}\text { A unit of time during which Wayne } \\
\text { gives an instruction to the dancers, } \\
\text { it can be a make, a task or a show. } \\
\text { it usually lasts around } 45-50 \text { min } \\
\text { and its is limited by pauses for } \\
\text { the dancers, so they can rest or } \\
\text { practice what they learned, or by } \\
\text { wayne's need to take notes on the } \\
\text { instructions. }\end{array}$ \\
\hline ָึֶ & $\begin{array}{l}\text { D, F, C, T quartet recapping and } \\
\text { figuring out the grips: C- you } \\
\text { know I will put some weight here? } \\
\text { F- Yes. C- who is carrying up the } \\
\text { weight no- T- I am carrying the } \\
\text { weight- D- Who is initiating it? }\end{array}$ & & & Mk & $\begin{array}{l}\text { Make on: W makes mvmt on specific } \\
\text { dancer(s) }\end{array}$ \\
\hline 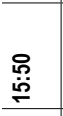 & $\begin{array}{l}\text { W arrives amd starts on } J \& L \\
\text { duet. He embodies } L \text {, snapps, } \\
\text { words, touches J. the other } \\
\text { dancers attending }\end{array}$ & Mk, Mod, At & $\begin{array}{l}\text { w seems to be very ener- } \\
\text { getic, very clear directions. } \\
\text { Very fast instruction.The } \\
\text { music is quite metronomic }\end{array}$ & S & $\begin{array}{l}\text { Show: W shows self-generated } \\
\text { mvmt to dancers }\end{array}$ \\
\hline \multirow[t]{2}{*}{$\begin{array}{l}\text { 菖 } \\
\text { ஸे }\end{array}$} & W "from there"... & $\begin{array}{l}\text { ModG,T, } \\
\text { Talk }\end{array}$ & & Task & $\begin{array}{l}\text { Task: W gives a task to dancers for } \\
\text { them to generate their own mvmt }\end{array}$ \\
\hline & $\begin{array}{l}\text { students sketching individually in } \\
\text { the background }\end{array}$ & $\mathrm{Ob}$ & $\begin{array}{l}\text { the dancers follow, stop } \\
\text { and look, ad continue, lots } \\
\text { of talking }\end{array}$ & St & $\begin{array}{l}\text { Structuring: The management of space } \\
\text { and yhe combination of elements inside } \\
\text { from one or several phrases to form } \\
\text { larger structures of movement that get } \\
\text { into the final performance. W positions } \\
\text { dancers on stage in relation to each } \\
\text { other, marks the dance rhythm, synchs } \\
\text { the dancers to the final music score, } \\
\text { and combines de dance material into a } \\
\text { choreographed phrase. }\end{array}$ \\
\hline 兽 & $\begin{array}{l}\text { W restarts the music and riffs, } \\
\text { while all the dancers practice }\end{array}$ & Rf, Practice & $\begin{array}{l}\text { w seems to be thinking, not } \\
\text { really watching the dancers }\end{array}$ & Practice & $\begin{array}{l}\text { Time in between instructions where } \\
\text { the dancers are either recapping, } \\
\text { refining, marking, sketching or doing } \\
\text { the movements full out, without } \\
\text { Wayne's direct attention. }\end{array}$ \\
\hline
\end{tabular}


Figure 1 and $2^{*}$

Continuation (video online ${ }^{*}$

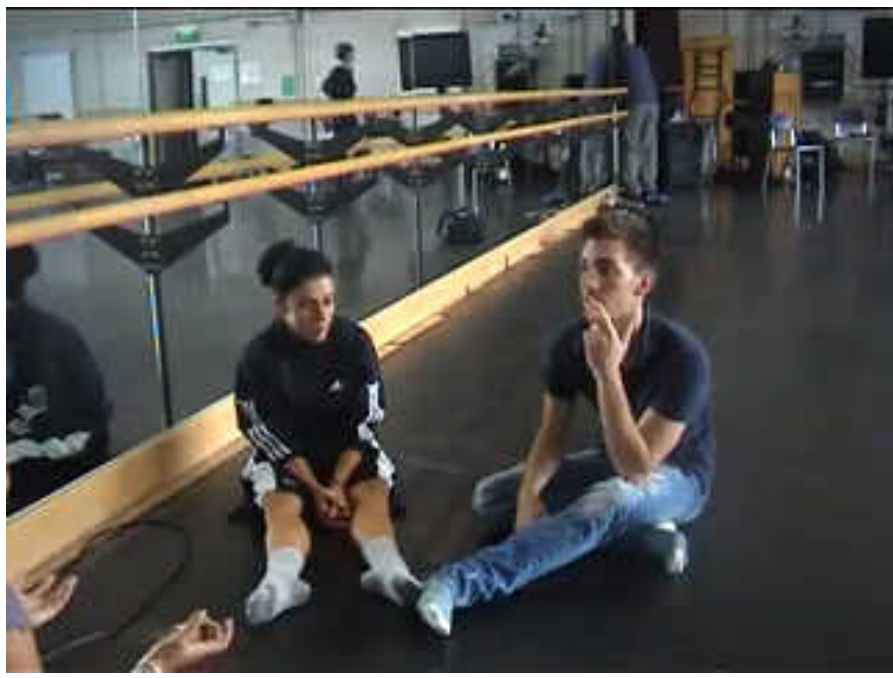

Audiovisual data has been coded and analyzed with ELAN, developed by the Max Planck Institute for Psycholinguistics, for gesture and small-scale interactions. Relevant episodes were coded as annotations with the ELAN audiovisual annotation tool. We inductively extracted codes from the audiovisual data, as well as from the field notes taken during the whole process. Audiovisual analysis needs a strong model or codification to start with, in order not to get lost with the data (Cicourel 1974). Through the classification of Activity Recurrent Episodes (or ARE), we traced the different types of instruction, and organized them by modality. ARE are "activity occurrences that are judged to be significant happening in the learning context and that are delimited by a change in theme" (Barab, Hay and Yamagata-Lynch 2001: 66).

Moreover, the concepts of differentiation and individualization of Simmel (1908) allow us to introduce two specific claims about the dancers' interaction patterns. According to the hypothesis of social differentiation, the quantitative expansion of the group leads to the differentiation or proliferation of groups (Simmel 1908). We want to see if the dancers

* The multimedia documents are the property of Wayne McGregor-Random Dance Company, London, together with David Kirsh, from the University of California, San Diego (UCSD). The interviewed dancers are Agnes López and Maxime Thomas. 
just look, ask or interact with the choreographer or assistant, or if they look and ask each other. Differentiation promotes individualization, since it increases the number of groups affiliated to a particular node (Simmel 1908: 146). Another hypothesis suggests that Simmelian sociological determination of the individual increases with the number of groups that overlap without being concentric. Network Analysis locates these multimodal forms of interaction by looking at the multiplicity of roles and the reality of group affiliation in creative networks, with UCINET software.

\section{Analysis 1. On Multimodal Functionality}

Rehearsals were structured in sixteen phrases, composed of a combination of four types of choreographic instructions: Tasks, Showing, Make On and Structuring. The names were extracted inductively from interviews and informal conversations, as well as field notes and video (Kirsh et al 2009). Initially, the choreographer proposed eight tasks to the dancers, cognitive exercises to produce dance moves based on visualizations, rhythms, sounds or tactile stimulation. Showing and making on consisted in the translation of movement created by the choreographer on one or more dancers, who became references for the other dancers. The choreographer intentionally kept the dance material unstructured until a couple of weeks before the premières. The

Figure 3.

The choreographer (left) performing a riff while attending to a female dancer's arm (right). (UCSD, 2010) (video online*).

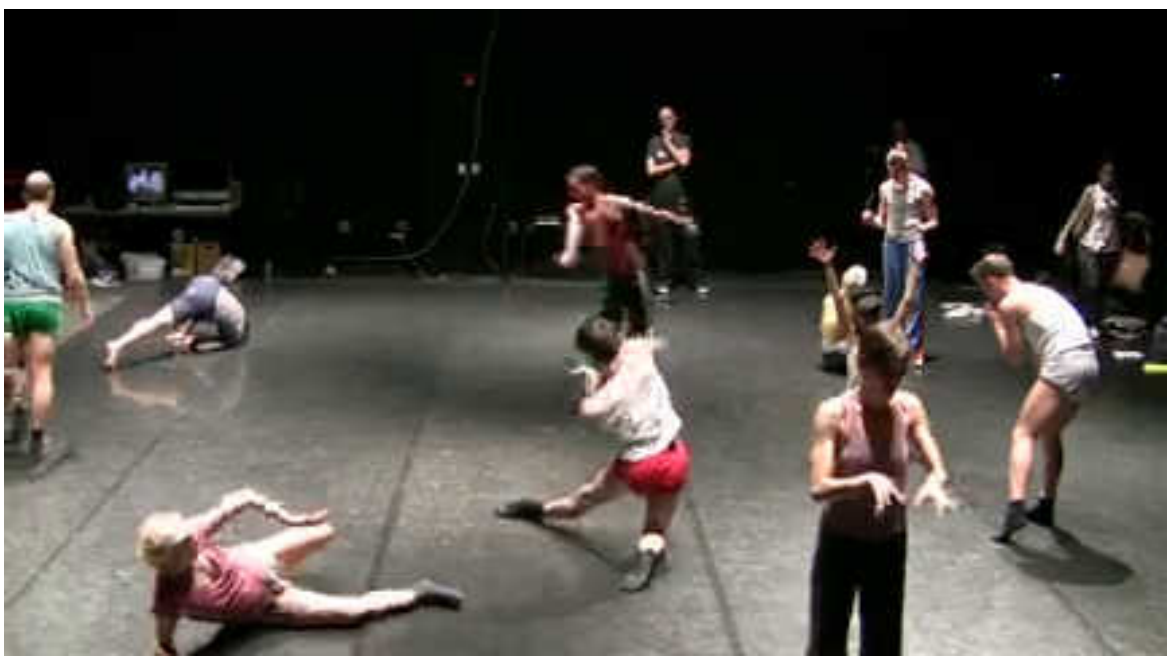


dancers created a lot of material from which the choreographer made a restricted final selection, to ensure the degree of heterogeneity required to reach an original and novel (ie creative in the professional jargon) dance piece. Both the choreographer and the dancers identify originality and innovation with creativity, which they define as a clearly embodied and contextual activity.

"I can only tell novelty when I see it, or feel it, or experience it. I can only do it t with the live matter present, I can't do it drawing it, or I can't really do it on a computer or anything like that. I really need to work through the siphon of a live experience (Wayne McGregor, interviewed by David Kirsh in London, July 2010)."

Multimodality, then, appears already at a phenomenological level:

" (A new movement performed by one of the dancers) certainly excites the curiosity in me. It would make my eye go: 'Oh, that's interesting!' and make me make a decision of whether I want that, or... It might be an absolute repulsion, 'I absolutely do not want it that way'. It's a strong feeling." (McGregor, interviewed by D. Kirsh in London, July 2010).

The choreographer describes his feelings when seeing a dance movement he likes (or dislikes). He describes his experience as a type of perception, primarily visual ('It would make my eye go...'); then emotional (using adjectives such as exciting or repulsive) and only later conceptual. This multimodal choreographic quality was first detected in riffing, a phenomenon observed during rehearsal. Riffing can be defined as a sequence of movements linked to the choreographer's act of perception, after which he might incorporate (or not) the movement of a dancer (in Figure 3) (Kirsh et al 2009). The dancers generate the movement while the choreographer develops a spectatorial attitude specific to rehearsals (Todes 2001). While the dancers improvise while solving a task, the choreographer is necessarily there, sharing the same physical space with the dancers in co-participation, and also a visual, auditory and symbolic field of production.

Some figures from classical ballet have been transmitted to modern dance, such as the duet or trio. As noted by dance theory and professionals themselves (Faure 2003; Carter 1998) gender stereotypes are powerful topos for the production of chorographical meaning. Audiences project almost universally and with no further thought an erotic relationship onto a classical duet, independently of the actual gender of the dancer. The erotic charge comes from the relative positions of the dancers, the role that each dancer has in the duet as a small- scale social institution.

In order to analyze the multimodal nature of instructions, phrases were chosen following a random selection process, with a handpicked solo as a comparison element for the data obtained from the duet-like structures. The dance phrases were mainly com- 
posed of duets, trios or quartets, and only some (5 out of 16 phrases) produced solos. Gender analysis of the distribution of tasks was effectuated on four phrases: two duets, one trio, and one solo. The phrases were divided into relevant episodes of activity, from an average of 59 to 85 divisions by phrase. The episodes had a variable duration, with a minimum average of 38 minutes for the trio, to 45,41 minutes for the solo (Muntanyola 2009).

Looking at Figure 4, we see that Words and Gesture is the first communicative modality for both genders. While in male duets it represents $81 \%$ of the total instructions received, in female dancers it drops to $75 \%$. In males interactions Words fall down to with $18 \%$ of Embodied interactions. In females the second option is Touch, with $22 \%$ of all interactions. One the one hand, the clear dominance of Words and Gesture among the choreographer and the male dancers in duets seem to reinforce the link between verbal expression and the attributes of masculinity (Ferrand, Imbert \& Marry 1999). On the other hand, the similar volume of frequencies in the second group indicates that the function of Touch in female dancers is similar to that of Embodiment in male interactions. The female physical attributes, grace and flexibility, is at the center of the duet as a romantic dance form. She is attributed with superior technical skill and body virtuosity. Therefore, the choreographer uses Touch to guide

Figure 4.

Modalities of Directive Interactions by phrase and gender (Muntanyola 2009)

Gender Distribution of Directive Interactions (\%)

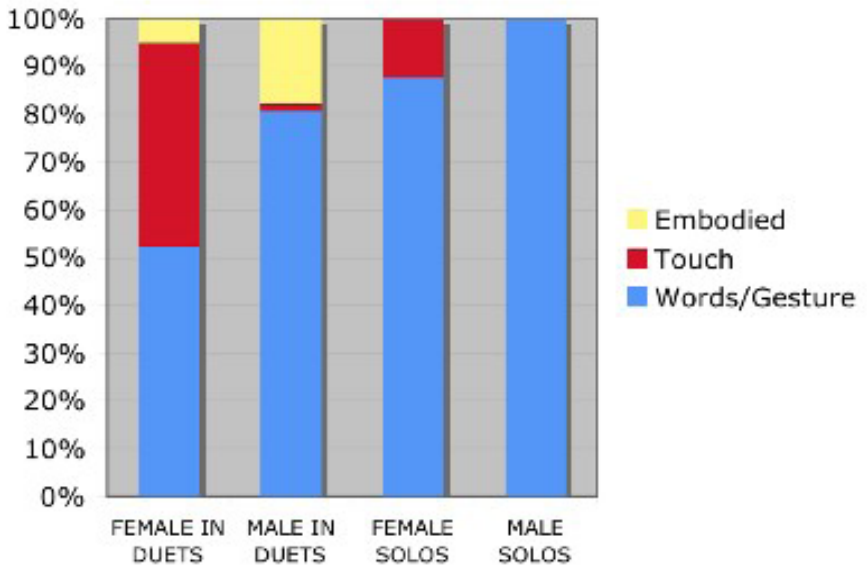


the female body in a specific, detailed way, obtaining from the dancer often difficult and extreme moves. Because of age and training, the choreographer lacks the physical capital that is required from both female and male dancers. Still, the choreographer takes the place of the male dancer to show exactly how to hold, follow or help the female dancer. He dances the role of being a supportive element, like a column or a pillow, for the female moves. Male dancers are attributed with specific gendered elements such as energy, strength and initiative that are more accessible to the choreographer's body techniques.

In order to further verify the multimodal nature of the choreographer's work in creativity, we analyzed a larger sample of phrases by type and gender, focusing on a single dance creation, FAR. Two summer session students, Susan Lunardi \& Eric Lansangan, analyzed 9 phrases following a distribution of solos, duets and trios, controlling for the gender variable (see figure 5 ).

Looking closely at the data we identified a new modality in use. We modified the coding scheme from the previous study (Muntanyola 2009) (figure 6). An initial analysis puts forward the simultaneous co-presence of multiple modalities, across phrase type (solo, duet, trio) and gender. Because of its large presence as a communication medium, gesture was considered independently from verbal interaction. We detected a correspondence between the action of embodying and the presence of sonification, which are sounds that the choreographer makes to help communicate when embodying what the dancers are supposed to do. Sonification corresponds better to what is understood as a modality, since embodiment comes closer to a type of action or activity. Refining the code and substituting embodied actions with sonifications allowed for more precision and accuracy.

Figure 5.

Selected phrases from FAR (Lunardi \& Lansangan in class, UCSD, 2011)

\begin{tabular}{lcccc}
\hline Cognitive Events & Verbal & Touch & Gesture & Sonification \\
\hline Make, Solo, $M$ & Yes & Yes & Yes & Yes \\
Make, Solo, $F$ & Yes & Yes & Yes & Yes \\
Make, Duet, M/M & Yes & Yes & Yes & Yes \\
Make, Duet, M/F & Yes & Yes & Yes & Yes \\
Make, Duet, F/F & Yes & Yes & Yes & Yes \\
Make, Trio, M/M/M & Yes & Yes & Yes & Yes \\
Make, Trio, M/M/F & Yes & Yes & Yes & Yes \\
Make, Trio, M/F/F & Yes & Yes & Yes & Yes \\
Make, Trio, F/F/F & Yes & Yes & Yes & Yes \\
\hline
\end{tabular}


Figure 6.

ELAN analysis with a redefined coding scheme.

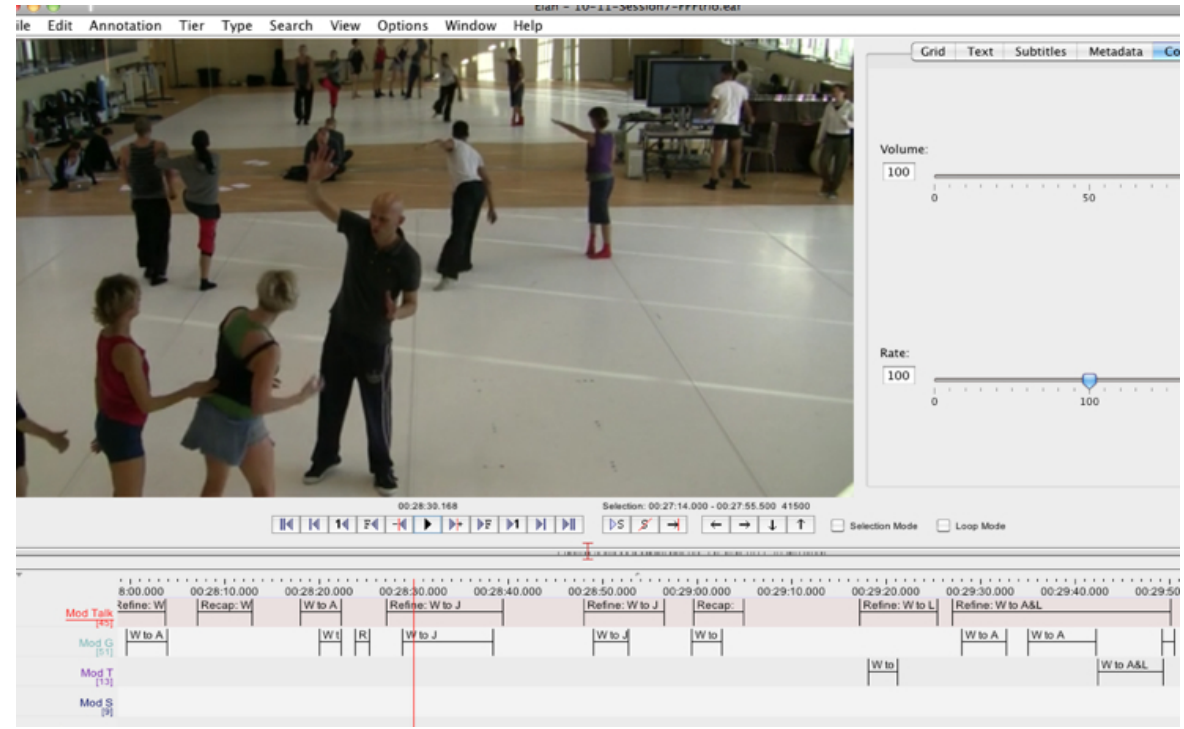

In figure 7, the distributed frequencies table in puts forward the co-occurrence of modalities in dance creation. Totals exceed $100 \%$ since the choreographer uses frequently two or more modalities simultaneously to communicate instructions to the dancers. Talk and gesture dominates, especially in duets and trios, followed by gesture at an average distance of $11 \%$. In solos this distance is reduced to $8 \%$, and the presence of talk is compensated by a large percentage of sonifications, $13{ }^{\prime} 8 \%$. In duets, the third dominating modality is touch, while in trios the weight is equally distributed among touch and sonification. These differences among phrases are an indicator of the functional specialization of the modalities observed in rehearsal.

The observation of video-ethnographic data with ELAN video archives puts forward the specificity of the information carried by each modality, and the complementarities of the different types of interactions. Sonification carried the shape, emphasis or dynamics of a phrase. The one- to- one character of such instruction can explain the larger presence of sonification in solos, where the identification of the choreographer with the dancer is stronger. On the contrary, the nature of duets as a self-contained form, as a romantic topos, puts forward the classic division of labor between a virtuoso female 
dancer and a strong male dancer. Touch becomes paramount to communicate the level of detail needed to explain a given position or a certain gripping point. Talk and gesture clearly dominate in trios, given the larger number of participants and the further need for coordination.

When taking the gender variable into account consolidates the commented pattern for phrases with all-female dancers. As we see in figure 8 , sonification in female solos goes up to $21^{\prime} 5 \%$, while in duets touch is used in $22 \%$ of the choreographer's instructions. Most striking is the strong dominance of talk in $90^{\prime} 7 \%$ of female trios, which matches our association between talk and higher levels of complexity. Female trios, because of the commented physical dexterity that is attributed to female dancers, include more acrobatics, further synchronization and a complex sequence of movements and transitions.

Figure 7.

Distribution of instruction modalities by phrase type.

\begin{tabular}{lcccc}
\hline Modality of Instruction (\%) & Talk & Gesture & Touch & Sonification \\
\hline Solos & 50.84 & 42.04 & 2.27 & 13.78 \\
Duets & 68.65 & 45.56 & 12.84 & 4.12 \\
Trios & 68.81 & 43.98 & 6.25 & 7.21 \\
Mean & 62.77 & 43.86 & 7.12 & 8.37 \\
\hline
\end{tabular}

Figure 8.

Distribution of modalities by type and gender (\%)

\begin{tabular}{c|c|c|c|c|c}
\hline Form & Gender & Mod Talk & Mod G & Mod T & Mod S \\
\hline Solo & M & 35.62 & 46.76 & 0.95 & 6.13 \\
\hline & $\mathrm{F}$ & 66.06 & 37.32 & 3.59 & 21.43 \\
\hline Duet & M/M & 40.65 & 55.98 & 4.12 & 4.20 \\
\hline & M/F & 85.91 & 37.21 & 13.16 & 3.66 \\
\hline & F/F & 79.40 & 43.48 & 21.25 & 4.49 \\
\hline Trio & M/M/M & 77.51 & 31.74 & 1.73 & 16.16 \\
\hline & M/M/F & 54.02 & 47.67 & 13.51 & 2.89 \\
\hline & M/F/F & 52.97 & 61.09 & 4.36 & 6.15 \\
\hline & F/F/F & 90.73 & 35.42 & 5.40 & 3.62 \\
\hline
\end{tabular}




\section{Analysis 2. Formalizing Interaction in Social Network Analysis}

In January 2010 we collected information about how the dancers in Random Dance followed chorographical instructions. We applied Social Network Analysis to the results of a survey presented to the dancers with the following questions:

Q1. Who do you follow the most? (Information Network)

Q2. Who do you ask for advice when you get stuck? (Advice Network)

Q3. With whom do you feel more comfortable working? (Friendship Network)

We distinguished between information-based interactions guided by visual perception (following another member of the company), those primarily verbal (asking for corrections or advice), and emotional and affective in nature (friendship and love). When answering the survey, all dancers said they followed the choreographer and his assistant. We removed their nodes from the personal networks in order to dig further into the distribution of information among the dancers. Half of the respondents reported that patterns of information and advice were situational, according to two factors: the proximity of the dancers (Asking or looking at those who are closer to the respondents in rehearsal), and the type of instruction (Show, make or task). The following results are an introduction to the possibilities of this new methodology. Our analysis followed a dual strategy. The dancer's responses produced three 11 by 11 matrices that integrates both the response of the dancers on their own ego network, as well as their subjective representation of what their peers usually do. On the one hand, we are dealing with a multiplex data structure that forms a shared cognitive social structure (or CSS).

Figure 9 shows the dialog box Data> CSS, which offers access to some specialized tools for the analysis of cognitive networks. CSS represents the actors' perceptions of the existing relationships between a set of nodes. Following the CSS function, we created Row-Ego networks based on the combination of egocentric dancers' networks.

Figure 9.

Screenshot of the UCINET function Data-CSS

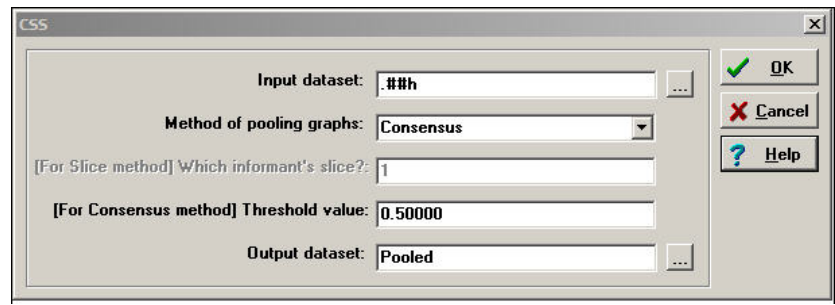


In order to define the three dimensions of interaction (information, advice and friendship) we applied the Row LAS function, which uses the row of each player as the input row in the resulting matrix. Each dancer becomes the "informant" on one's own output links (Own-Ties). CSS Networks were created by substituting with neutral values (0) the EGO row values corresponding to each respondent. Moreover, the items I, J (rows, columns) from each dancer were added. In order to perform the sum of matrices we used the UCINET function Tools> Matrix Algebra. Therefore, we distinguished, both mathematically and visually, the subjective representations of each individual dancer from the structural cognitive mechanisms of creation. We were able to explore the relationship between the positions of the dancers in the rehearsal network, and their individual perceptions.

We applied centrality measures (degree, closeness and betweenness) in order to explain the networks behavior. According to the type of network, CSS or EGO, we compared the degree of differentiation and individualization, through the presence of cliques and Simmelian ties, according to the dominant interaction modality (visual, verbal or affective).

In the CSS visual network, in Figure 10, we see how Antoine dominates both the input and output bonds, with 10 relationships. The average node degree in both directions is five, so the dancers look/are watched by an average of five peers. A higher in-degree is an indicator of the dancer's experience and prestige inside the company. It means that other dancers seek her advice, or follow her moves as a model for what the choreographer wants. Dancers with a high out-degree are better placed to exchange information with the rest of the company. Looking at the Ego visual network, also in Figure 10, we find differences between the projection of the dancers and their own individual responses. Dancers tend to inflate the number of relationships attributed to others. The distribution of information exists, but is less than the dancers imagine.

In the networks for verbal advice, in Figure 11, the node degree is around 6 in both input and output relationships: Antoine continues to be at the center of interactions, while the distribution of the other relationships follows similar patterns from the visual networks. Let's now examine whether the technical gossip (Knorr-Cetina 1999) that results from these two types of interactions corresponding to the bonds of friendship and trust between dancers which are represented in Figure 12. If these interactions overlapped with the first two networks, we would have trouble claiming that such interactions have informative and learning value other than the emotional content of friendship or familiarity. In both affective networks, with an average nodal degree of 5-7, the central position is no longer occupied by Antoine, who is below average, but by Angel, a dancer with low degree in the other two modalities. Therefore, while both visual and verbal networks follow similar centrality patterns, the network of friendship follows a different behavior.

We also applied a second measure of centrality, that of proximity or closeness, which includes all indirect relationships in the company. In order to correct excessive localization, we applied the Eigen factor, which takes into account the global structure of the network. According to this measure, the visual patterns of proximity are close to those 
predominantly verbal. In both CSS networks the average proximity is $75-76$, Antoine at the center with a 100 relationships. Its distribution follows that of the degree centrality. Finally, as a third centrality measure, we applied betweeness to all networks, which indicates geodesic distance among the nodes. It determines how many steps (with a minimal distance of 1 , or the direct interaction between nodes) separate one node from the rest. The ability to interconnect many nodes or agents gives prestige and power, but can also produce information overload or noise. In visual and verbal CSS networks, Antoine dominates. Ego networks behave differently: Antoine continues to lead, but is closely followed by Agnes, whose shared cognitive representation is below average. This polarization indicates that guessing the other's interactions is not easy. The difference between CSS and ego networks show how the shared cognitive perceptions are missing key dancers who act as bridges between the various factions of the company. Also, we are analyzing

Figure 10.

Ego and CSS Visual Networks (Information Function)
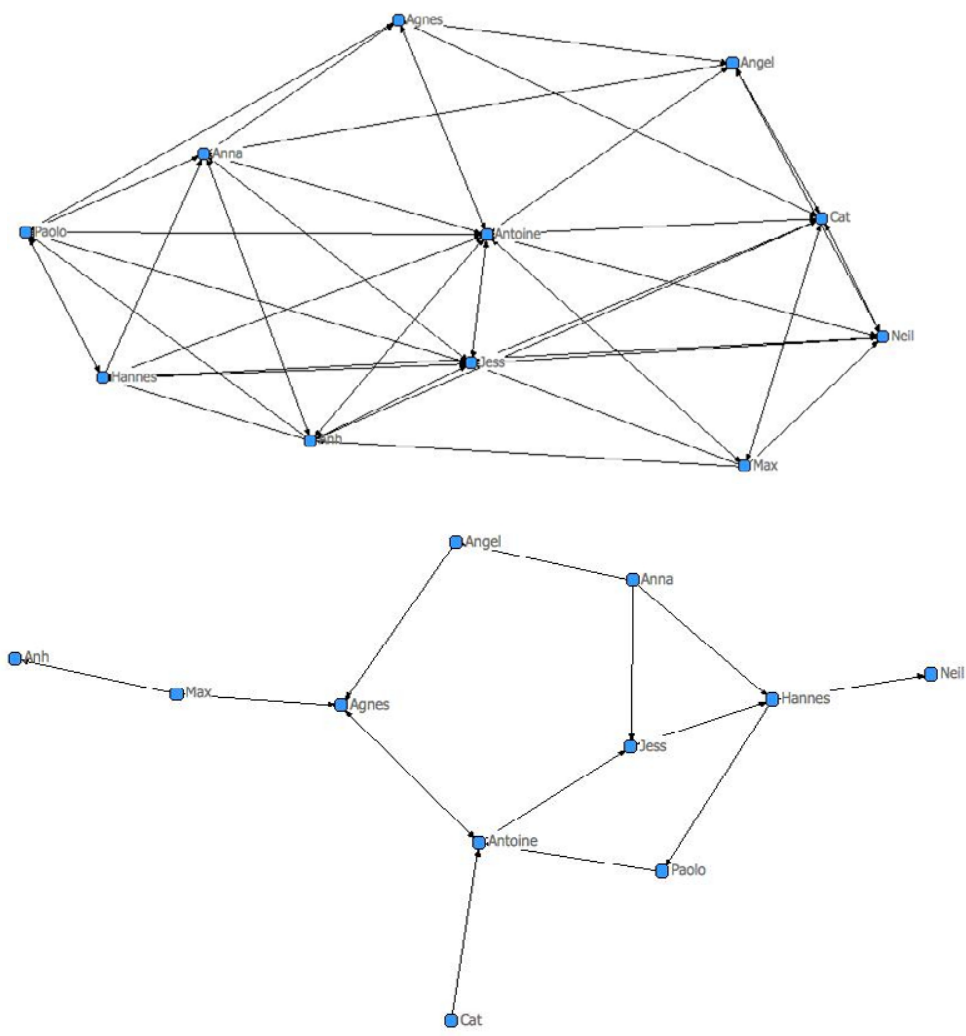
Figure 11.

Ego and CSS Verbal Networks (Advice Function)

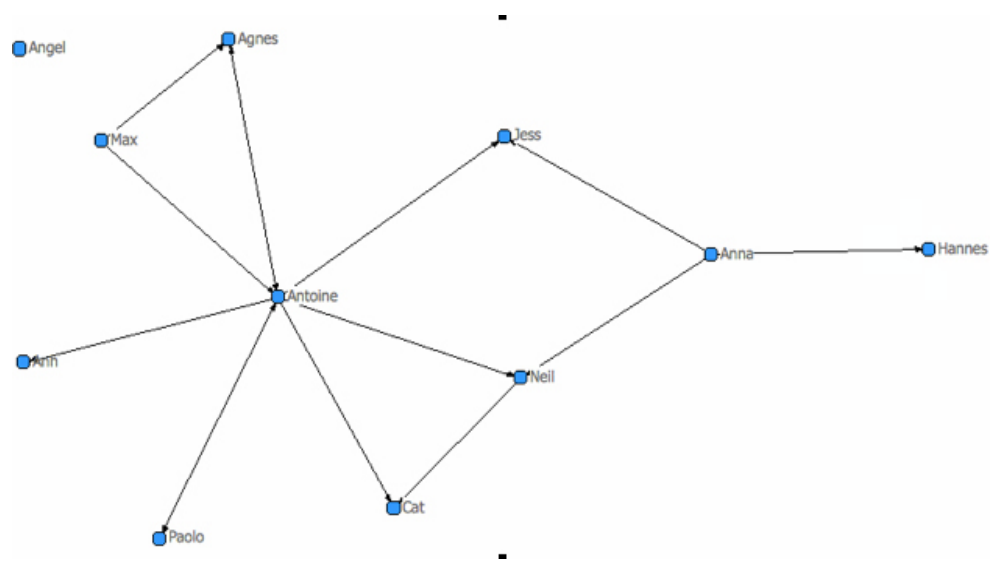

is very heterogeneous population: All networks' standard deviation exceeds $60 \%$, which probably gives way to the existence of local variations which explain largely the difference in the patterns of betweeness.

In addition to centrality measures, the analysis of groups and local factions inside the network gives us information on the degree of solidarity and accessibility of the cognitive creativity in the network. The analysis of the different types of triads in populations has been a staple of sociometry and social network analysis (Lozares 2003; Breiger 2000; Moreno 1953; Simmel 1908/1971). The minimum social structure with the character of a "society" is the triad - which in our case, will come down to any "triplet" $\{A, B, C\}$ of dancers. This structure "inserts" the dyadic relationships in a structure in which "others" are present along with "Ego" and "Alter".

Through the N-cliques UCINET function, we can determine the number of cliques with nodes linked by n-steps, which we limited to two, in order to include dancers who are indirectly connected with other members of the clique. We formed teams of a minimum of $g=3$ members, overcoming the dyad and giving way to a finite but rich combinatorial information game. The CSS visual network produces fewer cliques, 8 , but with a larger composition, with a minimum of 4 members and a maximum of 6 . Antoine belongs to all of them, followed by Cat \& Jess at a distance. In the ego visual network inflation occurs, as indicated in the centrality measures: 11 cliques with 2 or 3 members appear: Antoine belongs to 4 of them, followed by Hannes and Agnes. Such difference is explained by the higher number of interactions subjectively guessed in the ego networks, as opposed to the objective CSS networks. In the ego verbal network 8 cliques appear, with also 2-3 members: Antoine is part 5 of them, followed by Anna. Finally, in the friendship network 
Figure 12.

Ego and CSS Affective Networks (Friendship Function)
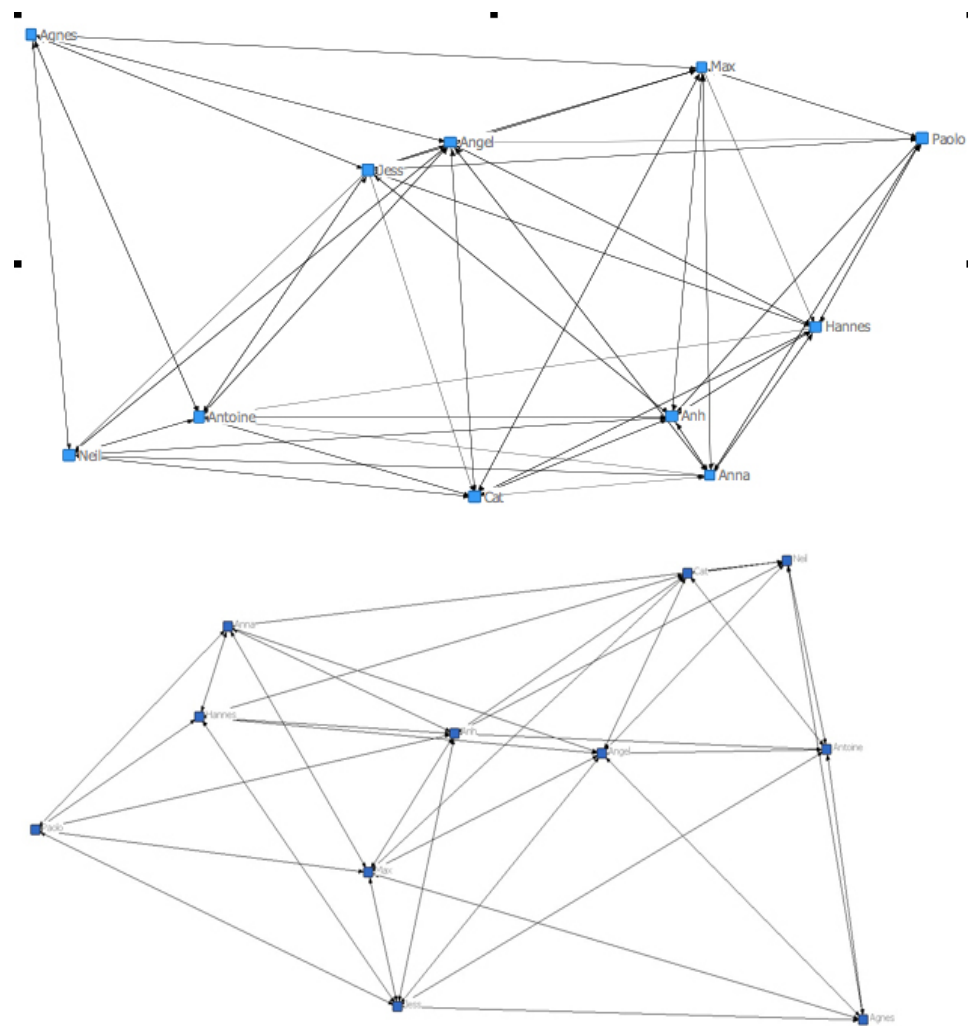

there is less overlap, with an average of 3 cliques, while the main node here is not Antoine but Cat. Again, the different pattern in affection shows that the other two types of interaction do not simply follow patterns of friendship or trust, but play a role in the functional distribution of information for learning new movements in rehearsal.

Smmelian ties, last measured applied in this case, explores intergroup density and, more specifically, the number of dancers who appear at the intersections. Looking at the commonalities between them, we can say that the null or full differentiation hypothesis does not occur. Interactions follow patterns that are not the result of random combinations. In Figure 13 Antoine is connected with all the nodes in the network, which goes well with the results in centrality measures and cliques that we have defined up until now. In Figure 14 the verbal network shows a roughly equivalent position of Antoine and Jess: they both have in common 6 nodes. Finally, in the friendship network Antoine is secondary again. 
Figure 13 and 14.

Visual and verbal Simmelian ties.
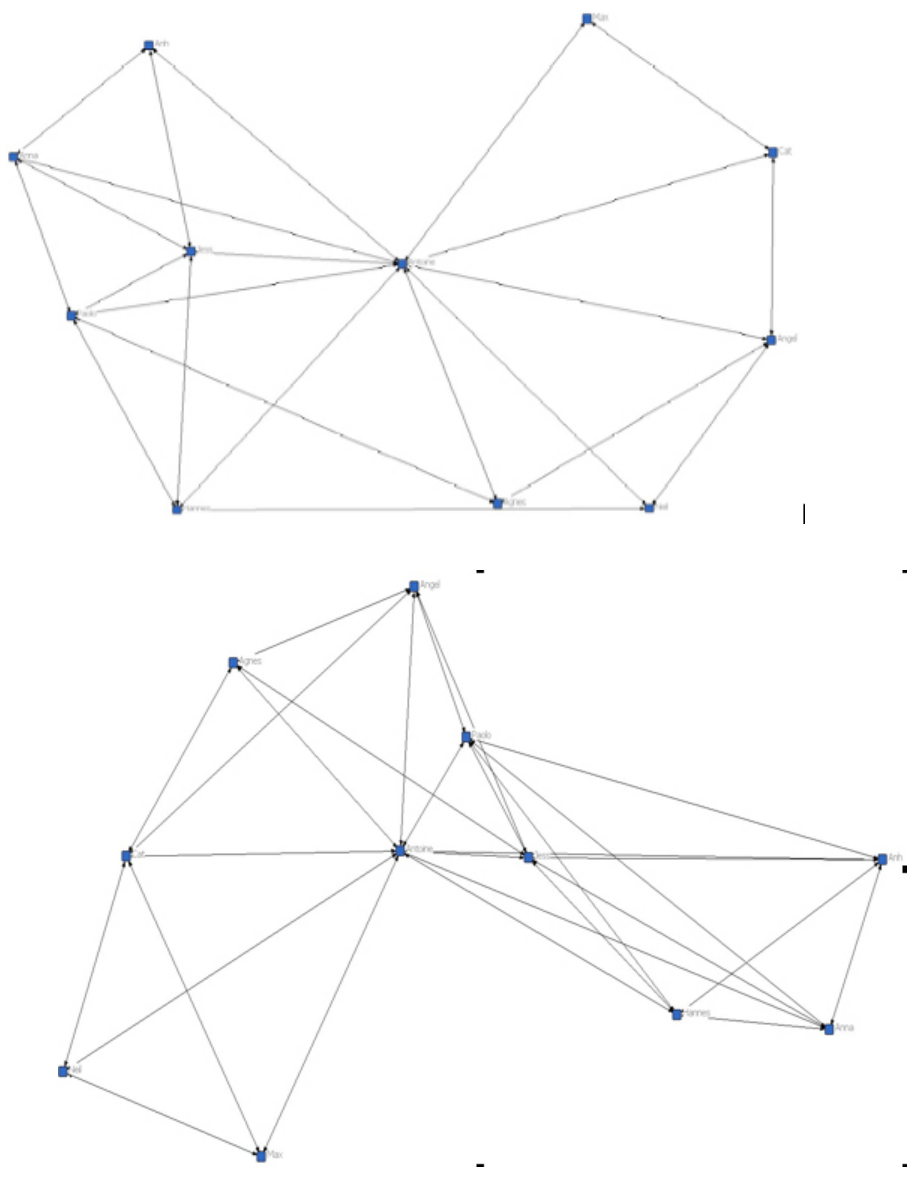

\section{Discussion and Conclusions}

In ballet, the transmission model defines a learning relationship where the dancer copies or follows à la lettre the choreographer's, and the other dancers' movements. The choreographer enters into a cannibalistic relationship with the dancer, whose body becomes an instrument for the exploration of choreographic imagination. We presented here two recent empirical studies that analyze micro sociologically the reality of instruction in rehearsals of a first-class neoclassical dance company. The important volume of 
choreographer's interactions using the modalities of Words and Gesture indicates that the observed choreographer's pedagogical model goes beyond classical transmission. Communication integrates other modalities, such as sonification and touch, and requires synchronization of simultaneous modalities at once. Still, the central place of the duet as a dance form does show an existing continuity with traditional narratives.

The exciting results of the detailed micro-observation of chorographical instruction pushed us to find a way to increasingly formalize our data In Muntanyola and Kirsh (2010), the introduction of Klein formalisms allowed us to define a cognitive strategy of skilled dancers, marking, as part of their skill for space management. Marking involves making a move in a summary form, with less time and effort. Thanks to geometrical analysis we made visible how the dancers' production of new and creative movements is based on the skill for improvisation and spatial management.

Following our secondary hypotheses, we examined the rehearsals' communication patterns, as well as the subjective perspective of both the dancers and the choreographers in daily interviews. The application of Social Network Analysis to behavioral data determined the degree of social interaction obtained among dancers according to centrality and Simmelian measures. Interactions here are indicators of the existence of relations of trust (Muntanyola 2010) and technical gossip (Knorr Cetina, 1999) that translate in communication patterns. Such interactions are the concrete manifestation of the choreographer's and the dancers' creative micro-decisions (Becker 1999). Our social network analysis locates the choreographer, and his assistant, as part of a socially distributed cognitive system consisting of dyads, triads and other forms of social interaction.

Respondents tend to give more names for their colleagues' interactions than for their own personal (ego) networks. The inflation or of estimated relations among dancers does not mean that distribution does not exist. Rather, the differences between the Ego and CSS networks shows how each actor's network is at least partially under the control of factors other than those which are strictly intentional. Once we eliminate the choreographer and his assistant from the matrices, another central figure, which we call filter figure, appears. The centrality measures show how the dancers' attention focuses on Antoine, who dominates all networks except the affective/ friendship network. The cliques and Simmelian ties confirm the power of Antoine as a filter for information. The difference between the information/advice patterns and the rest indicates that the distribution of information in rehearsal does not necessarily follow the friendship ties among dancers.

All measures indicate these differentiation and individualization processes do not follow random patterns. Specifically, betweeness centrality applied to CSS networks, which represent the dancers' mesh of cognitive structures, make visible those dancers that act as information bridges between different factions: Antoine in both visual and verbal networks, Agnes in visual interactions and Hannes in verbal interactions. These dancers are linked to the other members of the company at the time of rehearsal visually, when following a new choreographed movement, and verbally when there are specific points to clarify. The existence of moderate centralization, the presence of cliques and the high number of Simmelian ties confirm empirically the hypotheses of differentiation 
and individualization. Specifically, the existence of groups $(g>2)$ less than the whole of dancers $(n=11)$ leads to the falsity of the hypothesis of complete differentiation or null hypothesis. The existence of cliques with n-clan analysis allows us to identify the productive interactions that happen in rehearsal, that thus speak of the existence of distributed knowledge (Hutchins 2005; Hollan et al 2000), and multimodal in character (Alac 2005).

We believe that in social sciences it is possible to systematically analyze qualitative data coming from real work settings in naturalistic environments. The study of differences in social patterns of communication and action can help maintain or eliminate the cannibalistic relationship in dance. Future research will include further quantification of the information modalities that are pushed and pulled horizontally (between dancers) and vertically (with the choreographer). In interviews and rehearsals, we see how the dancers' self-awareness increases with verbal instructions. The dancers rely on the amount of verbal information that they get from the choreographer during instruction. Verbal instructions, as opposed to sonification or touch, push the dancers to verbalize and reflect on their creative work Verbal interactions among dancers might function as a compensatory mechanism to the insufficient feedback by the choreographer. Moreover, there is a high distribution of visual information, which is to say that the dancers look and talk to each other, and not only at the choreographer and his assistant. Other factors beyond the existence of friendly ties, such as the need for visual and verbal feedback among dancers, shape their creative interaction. Cognitive distribution seems to be a systemic requirement for the company to work as a creative team. After all, creativity is an individual activity, yes, but highly embodied and always happening in a social context.

\section{AKNOWLEDGMENTS}

I thank the Fulbright Comission for funding my research, and Wayne MCgGregor-Random Dance for allowing me to work as an ethnographer from 2009 to 2014 in the company. Thank you Susan Lunardi and Eric Lansangan, both students from UCSD, for their work in two of the figures of this paper. Last but not least, thanks to David Kirsh, director of this project and professor at the department of Cognitive Science, University of California, San Diego (UCSD) for opening up this line of work and teaching me how to do science.

\section{REFERENCES}

Alac, M. 2005. "From Trash to Treasure: Learning About Brain Images Through Multimodality". Semiotica 156: 177-202.

Barab, S., Hay, K. and Yamagata-Lynch, L. 2001. "Constructing Networks of Action-Relevant Episodes: An In Situ Research Methodology". The Journal of the Learning Sciences 10: 63-112.

Becker, H. 1999. Propos sur l'art. Paris: L'Harmattan. 
Bourdieu, P. 1998. Les regles de l'art. Paris: Seuil.

Breiger, R. L. 2000. "Control social y redes sociales: un modelo a partir de G. Simmel". Política y Sociedad 33: 57-72.

Buscatto, M. 2008. "L'art et la maniere : ethnographies du travail artistiques". Ethnologie française 38-1: 5-13.

Carter, A. 1998. The Routledge Dance Studies Reader. New York: Routledge.

Cicourel, A. 1974. Cognitive Sociology. New York: The Free Press.

Faulkner, R. and Becker, H. 2009. "Do You Know...?” The Jazz Repertoire in Action. Chicago: University of Chicago Press.

Faure, S. 2003. "Le Pouvoir de se raconter". Sociologie et societies 35(2): 213-31.

Ferrand, M., Imbert, F. and Marry, C. 1999. Excellence Scolaire: Une affaire de famille. Le cas des normaliennes et normaliens scientifiques. Paris: L'Harmattan.

Feyerabend, P. 1987. "Creativity - A Dangerous Myth". Critical Inquiry 13 (4): 700-711.

Hollan, J, Hutchins, E. and Kirsh, D. 2000. "Distributed Cognition: Towards a New Foundation for Human-Computer Interaction Research". ACM Transactions On Computer-Human Interaction 7(2): 174-196.

Hutchins, E. 2005. "Material Anchors for Conceptual Blends." Journal of Pragmatics 37:10-20.

Kirsh, D. Muntanyola, D., Lew, A., Jao, J. and Sugihara, M. 2009. "Choreographic methods for creating novel, high quality dance". Pp. 188-195 in Design and Semantics of Form and Movement 2009 Conference Proceedings. Taipei: Taiwan University.

Knorr-Cetina, K. 1999. Epistemic Cultures. Cambridge: Harvard University Press.

Lozares, C. 2003. "Valores, campos y capitales sociales". REDES, 4, 2. http://revista-redes.rediris.es/

Menger, P. M. 2002. Portrait de l'artiste en tant que travailleur. Paris: Seuil.

Moreno, J.L. 1953. Who Shall Survive? New York: Beacon House.

Morgenroth, J. 2004. Speaking of Dance. New York: Routledge.

Muntanyola, D. 2011. "Los músicos y el coreógrafo: opiniones cruzadas en danza”. Scherzo, 268: 24-29, Noviembre.

Muntanyola, D. 2009. "Coreographing Duets: Gender Differences in Dance Rehearsals". E-pisteme 3 (2) http://research.ncl.ac.uk/e-pisteme/

Muntanyola, D. 2010a. "Conocimiento experto y etnografía audiovisual: una propuesta teóricometodológica." EMPIRIA. Revista de Metodología de Ciencias Sociales 20:109-133.

Muntanyola, D. 2010b. "Danza y cognición: el proceso de creación coreográfica" J. Noya, M. Pérez \& F. del Val (Eds.) MUSYCA. Música, sociedad y creación artística. Madrid: Biblioteca Nueva.

Muntanyola, D., and Kirsh, D. 2010. "Marking as Physical Thinking: A Cognitive Ethnography of Dance". Proceedings of the IWCogSc-10 ILCLI International Workshop on Cognitive Science, Donosti, Universidad del País Basco. 
Muntanyola-Saura, D. 2011. "A cognitive account of expertise: Why Rational Choice Theory is (often) a fiction". Theory \& Psychology 24:19-39.

Rannou, J. and Roharik, I. 2006. Les Danseurs: Un métier d'engagement. Paris: La Documentation française.

Simmel, G. 1976 [1908]. "The Problem of Sociologie". Pp. 23-35 en Donald Levine (ed.) Georg Simmel on Individuality and Social Forms: Selected Writings. Chicago: Chicago University Press.

Sorignet, P. 2004. "Un processus de recrutement sur un marché de travail artistique: le cas de l'audition en danse contemporaine". Genèses 4 (57): 64-88.

Todes, S. 2001. Body and World. Cambridge: MIT Press.

Williams, R. 2006. "Using Ethnography to Study Instruction". Pp. 838-844 en Proceedings of the 7th International Conference of the Learning Sciences Lawrence University, Appleton International Society of Learning Sciences.

Dafne Muntanyola is Ph.D. in Sociology from the Universitat Autònoma de Barcelona (2008). Postdoc researcher in Nice and Madrid, and Fulbright Scholar at the department of Cognitive Science, University of California, San Diego (UCSD). Current research includes the study of expert and creative teamwork, crossing over the fields of contemporary cognitive science and ethnography (Muntanyola, 2010, 2014, \& Kirsh, 2010). She works on gender \& discourse too (Muntanyola, 2013, y Romero, 2013). She has translated Cicourel (2007) and Kirsh (2007).

\section{RECEIVED: 4 April 2013}

ACCEPTED: 26 February 2014

PUBLISHED ONLINE: 31 July 2014 